


\title{
ASSESSORIATÉCNICAÀ HABITAÇÃO EM VILAS E FAVELAS: A EXPERIÊNCIA DO ESCRITÓRIO DE INTEGRAÇÃO DO CURSO DE AROUITETURA E URBANISMO DA PUC MINAS ${ }^{1}$
}

\author{
TECHNICAL ADVICE TO HOUSING IN VILLAGES AND \\ SLUMS: THE EXPERIENCE OFTHE ESCRITÓRIO DE \\ INTEGRAÇÃO OF THE ARCHITECTURE AND URBANISM \\ SCHOOL OF PUC MINAS
}

Clécio Magalhães do Vale²

Maria Elisa Baptista ${ }^{3}$

\begin{abstract}
Resumo
Neste artigo, são tratadas propostas urbanísticas em áreas livres, fruto das desocupações por risco geológico e (ou) construtivo, visando à sua incorporação à vida coletiva da comunidade. Trata-se de um atendimento a comunidades com empreendimentos habitacionais previstos no Orçamento Participativo da Habitação, por meio do Programa de Produção de Conjuntos Habitacionais e Áreas Urbanizadas por Autogestão, da Prefeitura de Belo Horizonte, e selecionadas para o Programa de Crédito Solidário, do Governo Federal. O Escritório atuou nesse serviço por meio do Programa Arquitetura e Engenharia Públicas, buscando a reflexão sobre a possibilidade de elaboração de projetos habitacionais para a cidade informal, "regida" pelos parâmetros edilícios das ZEIS (Zonas Especiais de Interesse Social). A experiência aqui retratada corresponde ao período que se inicia em agosto de 2004 e se estende até dezembro de 2005.
\end{abstract}

Palavras-chave: Morro das Pedras; Empreendimentos habitacionais; Alternativas técnico-construtivas.

\begin{abstract}
In this article is treated the urban proposals in free areas effect of evictions by geological risk and/or constructive, for their incorporation into the collective life of the community (URBEL). It is about services to communities with housing developments planned in the Participatory Budget Housing, through Production Program Housing Complexes and Urbanized Areas for Self-Management by the Belo Horizonte city hall, and selected for the Federal Government program of Solidarity Credit (SMAHAB). The Escritório de Integração, worked through the Arquitetura e Engenharia Públicas Program, searching a reflection about the possibility of developing housing projects for the informal city, "regulated" by official parameters of the Special Zones of Social Interest. The experience depicted here corresponds to the period starting in August 2004 and extends through December 2005.
\end{abstract}

Keywords: Morro das Pedras, housing developments, technical-constructive alternatives. 